\title{
ELEMENTS OF ORGANIZATIONAL CULTURE THAT ENCOURAGE INNOVATION DEVELOPMENT
}

\section{ELEMENTOS DA CULTURA ORGANIZACIONAL QUE CONTRIBUEM COM O DESENVOLVIMENTO DA INOVAÇÃO}

Linda Jessica De Montreuil Carmona

Regional University of Blumenau - Brazil

Icarmona@furb.br

ORCID: http://orcid.org/0000-0002-0704-7165

Giancarlo Gomes

Regional University of Blumenau - Brazil.

giancarlog@furb.br

ORCID: http://orcid.org/0000-0003-1174-7161
Daniele de Lourdes Curto da Costa

Regional University of Blumenau - Brazil

Leonardo da Vinci University - Brazil

daniele.costa@uniasselvi.com.br

ORCID: http://orcid.org/0000-0002-6888-6165

Data de submissão: || nov. 2019. Data de

aprovação: 0 l fev. 2020. Publicação: 31/03/2020.

Sistema de avaliação: Double blind review. Universidade

FUMEC/FACE - Belo Horizonte - MG - Brasil. Prof. Dr.

Mário Teixeira Reis Neto e Prof. Dr. Cid Gonçalves Filho.

\section{ABSTRACT}

This study aims at analyzing the elements of organizational culture that foster innovation development in the Brazilian textile industry. Based on the Martins and Martins (2002) theoretical framework, an exploratory and quantitative survey was developed with primary data obtained from a survey applied to 587 employees of different organizational levels of 64 textile firms, using the following dimensions of culture: strategy, structure, support mechanisms, behaviors that stimulate innovation and communication. The multivariate treatment of data was performed using exploratory factor analysis. The results pointed to a model of analysis that empirically regroups and validates the determinants of innovation in three dimensions: strategy, stimulus to innovation and communication, avoiding the overlapping of items, an aspect criticized by several authors. The implications of research can allow managers to determine how organizational culture can better promote innovation, a key issue in highly competitive environments.

\section{KEYWORDS}

Organizational culture. Cultural factors. Innovation. Innovation development. Textile industry. 


\section{RESUMO}

Este estudo teve como objetivo analisar os elementos da cultura organizacional que favorecem o desenvolvimento da inovação na indústria têxtil. Baseado no modelo teórico de Martins e Martins (2002) foi desenvolvida uma pesquisa exploratória e quantitativa com dados primários provindos de survey aplicado em 587 funcionários dos diversos níveis organizacionais de 64 empresas têxteis, utilizando como base as dimensões de cultura: estratégia, estrutura, mecanismos de suporte, comportamentos que estimulam à inovação e comunicação. $O$ tratamento multivariado dos dados foi realizado mediante análise fatorial exploratória. Os resultados apontaram a um modelo de análise que reagrupa e valida os determinantes da promoção da inovação, em três dimensões: estratégia, estímulo à inovação e comunicação, evitando a sobreposição de itens, aspecto criticado por diversos autores.As implicações da pesquisa podem permitir aos gestores determinar como a cultura organizacional pode promover melhor a inovação, assunto essencial em ambientes de alta competitividade.

\section{PALAVRAS-CHAVE}

Cultura organizacional. Fatores culturais. Inovação. Desenvolvimento da inovação. Indústria têxtil.

\section{INTRODUCTION}

Early studies concur that organizational culture contributes to the intensity in which innovative and creative behavior is generated and disseminated among work teams. Organizational changes resulting from innovative behaviour promote and increase competitiveness, generating transformations in strategy, work systems, technologies and management styles, becoming a source of sustainable strategic competitive advantage (AHMED; OTHMAN, 20I7; BARNEY, I986; MARTINS; TERBLANCHE, 2003; OECD, 20I5; ZHENG; YANG; MCLEAN, 20I0). According to Barney (I986), organizational culture manifests itself in the way a firm conducts its business, through a strong set of values that drive the firm to superior financial performance, fostering flexibility and innovativeness.

However, there is no consensus on what kind of culture promotes and supports creativity and innovation (DOBNI, 2008; MARTINS; MARTINS, 2002). It is understood here that the term 'organizational culture' represents the values and beliefs rooted and shared by people within the firm, manifested in the most common characteristics of organizations, which can act in two ways: first being the part that interconnects all the links of the firm, and second, as an active component of the process of change (MARTINS;TERBLANCHE, 2003; SCHEIN, 2017).

The relationship between innovation and culture is very well documented in literature, associating organizational in- 
novation with cultures that support and commit to learning and participative decision making, which is directly related to success of new products and better performance (AHMED, 1998; DOBNI, 2008; HURLEY; HULT; KNIGHT, 2005; TIAN et al., 20 18). Moreover, linking the capacity of successful firms to absorb innovation into their organizational culture, socialization processes, organizational structure, and management processes, which allow innovation and competitiveness to expand (PETRAKIS; KOSTIS; VALSAMIS, 20I5; TUSHMAN, 1997).

Conversely, this relationship seems to create a paradox: on one hand, organizational culture acting as a promoter of creativity and innovation necessary to be competitive and successful and on the other hand, as a potential problem or even an obstacle, since in volatile environments, culture becomes more difficult to manage and resistant to change (AHMED, 1998; MARTINS; MARTINS, 2002; NARANJOVALENCIA; JIMENEZ-JIMENEZ; SANZVALLE, 20 I7). Jaskyte and Kisieliene (2006) suggest that a strong organizational culture can difficult innovation and alter the firm's capability of reacting to change, becoming "cult-like", while creating loyalty, uniformity, and commitment among members.

In this context, this research sought to analyze the elements of the organizational culture that foster innovation development on textile firms of the States of Santa Catarina and Parana, in the Southern region of Brazil. Although some cultural aspects contributing to innovation have been identified, the understanding of ideal cultural practices still has inconsistencies, particularly in the ability to sustain innovation in the long run (AHMED, 1998). Anderson
(2017) posits that even with the pervasive understanding that innovation is a 'must' in organizations, there are still many challenges to its full comprehension, such as cultural, organizational and societal.

In addition, it is necessary to comprehend the relationship between organizational culture and innovation in a more structured and systematic way (LEMON; SAHOTA, 2004). Some critics of the theoretical models that analyze the relationship between culture and innovation, point to the overlapping of some aspects of analysis, highlighting that it is necessary for more careful analysis, to access to the operational definitions of the factors (FARIA; FONSECA, 2014). According to Naranjo-Valencia; Jiménez-Jiménez e Sanz-Valle (20ll), despite the importance given to culture as a stimulant of innovation, empirical research remains limited, with most of the studies focused on some cultural characteristics, not on models of cultural values. Nkosi and Roodt (2004) add that there are vast methodological differences among the different conceptualizations of organizational culture.

The contribution of this study is based on the regrouping of dimensions and variables in order to refine complement and empirically validate the model of analysis of the relationship among the elements of organizational culture and innovation in the context of a developing economy, such as Brazilian's. The elements of culture that encourage innovation are critical characteristics that contribute to a developing economy's growth and competitiveness (UZKURT et al., 20l3).

The choice of the textile industry is justified by its importance to the Brazilian economy (GOMES; DEL PRÁ NETTO 
MACHADO; ALEGRE, 20I5; PADILHA; GOMES, 2016). The textile sector, which includes spinning, weaving, finishing, and textile confection, is world-renowned for its dynamism and turnover. Among world producers, Brazil occupies the fifth position among the largest textile producers with an annual production of 5.9 billion pieces (ABIT, 20I8). As far as the State of Santa Catarina is concerned, in 2018, it had ca. 10.000 manufacturers installed, which represents 18 percent of the national total, which means that 21.8 percent of the Brazilian textile workers are allocated there. The State also produces 17 percent of the national total of textile items (including clothing, technical and industrial apparels) (FIESC, 20I7). About the textile industry of the State of Parana, it produces around I50 million pieces with revenues close to I billion dollars (ABIT, 20I7).

This study is structured in four sections beyond this introduction. In the following section, relevant academic literature on culture and innovation is reviewed, followed by methodological procedures employed to collect data from 587 respondents belonging to 64 Brazilian textile enterprises. After presenting data analysis and discussion of the results, final remarks are made, pointing out the implications and recommendations for future research.

\section{THEORETICAL FRAMEWORK}

In this section, the concepts that offer theoretical support for the development of this paper are presented.

\section{Organizational Culture and Innovation}

To understand the organizational culture it is crucial to comprehend the un- derlying assumptions about how a group perceives, thinks, and feels. Organizational culture is an adaptation of broader cultural paradigms inserted into groups that are together long enough to share problems or have the opportunity to solve these problems and observe the effects of the solutions (SCHEIN, I 984, 1993, 2017).

According to Schein (20I7), organizational culture can be defined as a model of basic assumptions that a group invented, discovered or developed starting from a learning process seeking to adapt to a problem of external or internal order to the organization. For Pettigrew (1979, p. 574), it represents "... the system of such publicly and collectively accepted meanings operating for a given group at a given time", being symbol, language, ideology, belief, ritual and myth, its materializations.

The roots of the study of organizational culture can be found mainly in Anthropology. In the 1970s, an analysis gap for symbolic aspects was perceived in the field of business, because organizational descriptions - of a functionalist nature - were based exclusively on the analysis of tangible organizational structures, such as rewards or leadership, ignoring a fundamental aspect in organizational life: organizational symbolism, which is related to the aspects that an organization uses to highlight its 'unconscious feelings, images and values' (DANDRIDGE et al., 2008; DANDRIDGE; MITROFF; JOYCE, 1980).

The term 'culture' is relevant to organizations as they are viewed as social instruments and as a particular form of human expression (SCHEIN, 20I7; SMIRCICH, 1983). Thus, organizational culture can be understood as the social or normative glue that an organization holds, which is ex- 
pressed by the social values or ideals that its members share (LOUIS, I98I; SMIR$\mathrm{CICH}, 1983)$. Schein (2017) arguments that the strength of a culture can be defined by the homogeneity and stability of the group and by the duration and intensity of the experiences shared within it.

Martins and Terblanche (2003) analyze the importance of innovation and creativity in the corporate culture, indicating that in organizations based on knowledge, the success and survival of these, depending on creativity and innovation, discovery and originality. The result is that organizations foster the creation of an institutional environment in which creativity and innovation are accepted as cultural norms in changing environments.

The term innovation is often associated with change. However, this association is not always possible or plausible, since change does not necessarily bring new ideas or the perception of real improvement to the organization. Achieving innovation requires both the exploration of new opportunities and the improvement of existing capabilities (ANDRIOPOULOS; LEWIS, 20I0; MARTINS; TERBLANCHE, 2003; TIAN et al., 20I8).

Andriopoulos and Lewis (2010) add that as change accelerates rivalry and intensifies customer expectations, concern for innovation is a constant in organizations. Innovation involves identifying tools, ideas, and opportunities to create new or improved products or services.And in this sense, one of the most important assets is people with creativity, innovation and heuristic capabilities. In addition, innovation capability promotes competitive advantage that is essential for organizational performance, adaptation and long-term survival (BARNEY, I 986; HU, 20I2).

For Tushman (1997), culture is at the center of the development of innovation and the basic elements previously highlighted as shared values, beliefs, behaviors, influence the development of innovation. This influence can occur in two ways: through the process of socialization in which individuals learn acceptable behaviors and activities and, also when values, assumptions, and beliefs become established behaviors, influencing firm structure, management policies, and practices.

Martins, Martins, and Terblanche (2004) posit that it is necessary to explain that the terms of creativity and innovation are often used in the literature as synonyms and, therefore, it is important the differentiation of both. Some concepts of creativity focus on the natural process and intellectual activity used to conceive new insights or solutions to problems, while other definitions focus on personal characteristics and individual abilities. Thus, creativity can vary among groups, organizations or cultures (MARTINS; MARTINS;TERBLANCHE, 2004). In contrast, the concept of innovation is understood as the realization or recombination of new practices or methods (SCHUMPETER, 1997). The implementation of innovation in an organization occurs from new ideas or behaviors and can happen from a new product or service, a new process technology, a new administrative structure or system, a new plan or program produced by members of the organization (DAMANPOUR, 199I; DAMANPOUR; SZABAT; EVAN, 1989; OECD, 2005).

\section{Cultural Factors that Encourage Innovation}

Martins and Martins (2002) point out the lack of agreement among theorists about the factors determining the influence of organizational culture on innovation, and 
propose an integrated interactive model, based on literature findings, especially on the work of Schein $(2017,1984)$.Thus, these authors adopt a holistic systemic model in order to identify the complex interaction between organizational subsystems: organizational goals, values, structure, technology, management and psycho-sociologic subsystem, covering different levels of individuals and groups, including the external environment, which are seen as the primary determinants of behaviour at work (MARTINS; MARTINS; TERBLANCHE, 2004; MARTINS; TERBLANCHE, 2003).

This model has the following determinants: strategy, structure, support mechanisms, behaviors that stimulate innovation and communication. 'Strategy', which includes the organization's essential goals and values, is seen as a facilitating factor for innovation as it promotes the development and implementation of new products and services. Creativity and innovation are found in the organization's vision and mission, which must be future-oriented and customer/client-centered (MARTINS; MARTINS; TERBLANCHE, 2004; MARTINS; TERBLANCHE, 2003). Strategic orientation defines the organizational learning context and directs the search for new knowledge and opportunities (FAHIM; ROHAIZAT, 20I7; ZDUNCZYK; BLENKINSOPP, 2007). One of the effects of organizations' mission statement and vision is their influence on the creation of a strong culture, able to properly guide behaviors and actions (AHMED, I998; OUCHI, I98I).

Yet when vision and mission are market-oriented and focused on problem-solving, the organizational 'structure' may emphasize certain values of innovation, enabling effective innovation management
(CORMICAN; O'SULLIVAN, 2004). When the firm has a flexible structure, which promotes autonomy, it also promotes innovation. However, when the structure is formalized and centralized it can inhibit innovation (MARTINS; TERBLANCHE, 2003; ZDUNCZYK; BLENKINSOPP, 2007).

In relation to the 'support mechanisms', these must be evident in the culture of the organization to provide an environment that promotes creativity and innovation, such as reward and recognition, resource availability i.e. time, information technology and creative people (MARTINS; TERBLANCHE, 2003). The motivation most associated with creativity is characterized by leadership encouragement and socio-emotional support, competence, self-determination through work, increased autonomy and better opportunities for personal growth (AMABILE et al., 2004; MURAT AR; BAKI, 20I I).

'Behaviors that stimulate innovation' are characteristic of a participative working environment and common in flexible and open organizations that foster a culture of innovation based on trust among the involved actors (CORNEJO; MUÑOZ, $2010)$. In this sense, the way organizations handle employee mistakes directs this behavior. Successful organizations reward success and acknowledge or even commemorate failures, creating opportunities to openly discuss and learn from mistakes (MARTINS; MARTINS; TERBLANCHE, 2004; MARTINS; TERBLANCHE, 2003). For Ahmed (1998) it is critical that employees are aware of the risks they can take safely. Understanding risk provides a clear definition of priority and space for innovative actions.

An organizational culture that supports 
open and transparent 'communication', based on trust, will have a positive influence on the promotion of creativity and innovation (MARTINS; MARTINS;TERBLANCHE, 2004; MARTINS; TERBLANCHE, 2003; NDUBISI; AGARWAL, 20I4). Dombrowski et al. (2007) argue that communication barriers need to be eliminated and it is important for organizations to provide a culture of horizontal, democratic communication in order to attract and retain talented people that are necessary for the pursuit of experimentation and innovation. This is confirmed by Damanpour (I99I), who, in a study of the antecedents of organizational innovation, found that attitude towards change and external and internal communication are positively related to innovation.

\section{METHODOLOGY}

In order to analyze the influence of the elements of organizational culture that foster innovation development in the Brazilian textile firms, this quantitative and descriptive study (RICHARDSON, 2007), used primary data collected by a survey for tabulation, analysis, and conclusions, supported by the use of statistical software.

\section{Data and Variables}

Non-probabilistic convenience sampling was used in this study, which involves easily accessible firms and respondents willing to participate (TEDDLIE; YU, 2007). This selection looked for companies that were aligned with the objective of the study and could contribute to answering the research question. The choice of the specific social subjects of the research was at the discretion of the organizations, but a sample of all organizational levels was requested. Therefore, all the employees of the surveyed organizations, belonging to the top management level, unit management, group leadership, and operational level, were considered. The sample of this research was composed of 64 companies in the textile segment. Of these, 27 are located in the state of Santa Catarina and 37 in the State of Parana (see Table I).

Regarding the size, small, medium and large companies were selected, with the majority (32 companies) being small, according to Table 2 .

Table 3 shows that the sample of this research was 587 respondents belonging to 64 textile organizations. The largest number of organizations in the sample corresponds to the apparel industry, manufacturing personal clothing (for women, men, and children) and linen (bed, table, and bathroom). A characteristic of the garment segment is that it demands productive flexibility for the adjustment of organizations to new fashion trends.

The questionnaire used for data collection contained 26 questions, and the assertions should be answered using a Likert scale, with scores varying from I ("I totally disagree") to 7 ("I totally agree") using five determinants: strategy, structure, support mechanisms; behaviors that stimulate innovation and commu-

TABLE 1 - Geographic Location of the surveyed firms and respondents

\begin{tabular}{l|c|c|c|c}
\hline \multirow{2}{*}{ State } & \multicolumn{2}{|c|}{ Organizations } & \multicolumn{2}{c}{ Respondents } \\
\cline { 2 - 5 } & Frequency & Percentage & Frequency & Percentage \\
\hline State of Santa Catarina & 27 & 42.19 & 467 & 79.56 \\
\hline State of Parana & 37 & 57.81 & 120 & 20.44 \\
\hline Total & 64 & 100.00 & 587 & 100.00 \\
\hline
\end{tabular}

Source: developed by the authors. 
TABLE 2 - Sample by firm size

\begin{tabular}{c|c|c|c|c}
\hline \multirow{2}{*}{ Size } & \multicolumn{2}{|c|}{ Organizations } & \multicolumn{2}{c}{ Respondents } \\
\cline { 2 - 5 } & Frequency & Percentage & Frequency & Percentage \\
\hline Large & 15 & 23.44 & 136 & 23.17 \\
\hline Medium & 17 & 26.56 & 279 & 47.53 \\
\hline Small & 32 & 50.00 & 172 & 29.30 \\
\hline Total & 64 & 100 & 587 & 100 \\
\hline
\end{tabular}

Source: developed by the authors.

TABLE 3 - Type of activity of the surveyed organizations

\begin{tabular}{|c|c|c|c|c|}
\hline \multirow{2}{*}{ Type of Activity } & \multicolumn{2}{|c|}{ Organizations } & \multicolumn{2}{|c|}{ Respondents } \\
\hline & Frequency & Percentage & Frequency & Percentage \\
\hline Men's and women's clothing & 42 & 65.63 & 325 & 55.37 \\
\hline Outsourcing / Finishing & 4 & 6.25 & 13 & 2.21 \\
\hline Industrial embroidery & 2 & 3.13 & 10 & 1.70 \\
\hline Printworks & 1 & 1.56 & 4 & 0.68 \\
\hline Children's clothing & 1 & 1.56 & 21 & 3.58 \\
\hline Industrial Laundry & 8 & 12.50 & 37 & 6.30 \\
\hline Sports apparels & 2 & 3.13 & 86 & 14.65 \\
\hline Labels & 1 & 1.56 & 27 & 4.60 \\
\hline Bed, table, and bath & 2 & 3.13 & 39 & 6.64 \\
\hline Medical and hospital products & 1 & 1.56 & 25 & 4.26 \\
\hline Total & 64 & 100.00 & 587 & 100.00 \\
\hline
\end{tabular}

Source: developed by the authors.

nication (GOMES et al., 20I5; MARTINS et al., 2004; MARTINS and MARTINS, 2002; MARTINS and TERBLANCHE, 2003; PADILHA and GOMES, 2016).

According to the literature review and based on the objective of analyzing the relationship between the elements of organizational culture and innovation of textile firms, the determinant elements/dimensions, factors and empirical studies that used these variables, are presented in Table 4.

\section{Data Analysis}

In order to verify the initially proposed objective, an Exploratory Factor Analysis (EFA) technique was used, which, according to (CORRAR; PAULO; DIAS FILHO, 2007, p. 57), "searches through the evaluation of a set of variables, the identification of dimensions of common variability that exist in a set of phenomena".

\section{ANALYSIS AND DISCUSSION OF RESULTS}

First, the analysis with the 26 original variables of the questionnaire was performed. The variable Stimulus 5 presented a negative correlation; therefore it was excluded from the analysis. Table 5 shows the description of the 25 remaining variables of the model.

It was noticed that the means of the 'strategy' questions had relatively low amplitude, of 4.66 to 5.45 , highlighting the lowest mean in the question related to the alignment of personal and organizational goals (strategy4). And the highest mean for the perception of mission focus and vision in the future (strategyl). It should be noted that the strategy element has both the highest mean and the lowest standard deviation of the whole dataset (I.433), meaning a tendency to consensus. 
TABLE 4 - Research Constructs

\begin{tabular}{|c|c|c|}
\hline Dimensions & Factors & Authors \\
\hline \multirow{3}{*}{ Strategy } & Vision and mission & \multirow{3}{*}{$\begin{array}{l}\text { (ARAD; HANSON; SCHNEIDER, 1997; GOMES; DEL } \\
\text { PRÁ NETTO MACHADO; ALEGRE, 2015; GOMES; } \\
\text { MACHADO; ALEGRE, 2015; MARTINS; MARTINS; } \\
\text { TERBLANCHE, 2004; MARTINS; TERBLANCHE, } 2003 \\
\quad \text { MURAT AR; BAKI, 2011; NKOSI; ROODT, 2004) }\end{array}$} \\
\hline & Purposefulness & \\
\hline & Means to achieve objectives & \\
\hline \multirow{3}{*}{ Structure } & Flexibility & \multirow{3}{*}{$\begin{array}{l}\text { (GOMES; MACHADO; ALEGRE, 2015; MARTINS; } \\
\text { MARTINS, 2002; MARTINS; TERBLANCHE, 2003; } \\
\text { MURAT AR; BAKI, 2011; NKOSI; ROODT, 2004) }\end{array}$} \\
\hline & $\begin{array}{l}\text { Freedom (autonomy, empowerment, } \\
\text { decision, making) }\end{array}$ & \\
\hline & Cooperative teams and group interaction & \\
\hline \multirow{3}{*}{ Support Mechanisms } & Reward and Recognition & \multirow{3}{*}{$\begin{array}{l}\text { (AMABILE et al., 1996; GOMES; MACHADO; ALEGRE, } \\
\text { 2015; MARTINS; MARTINS; TERBLANCHE, 2004; } \\
\text { MARTINS; TERBLANCHE, 2003; MURAT AR; BAKI, } \\
\text { 2011; NKOSI; ROODT, 2004) }\end{array}$} \\
\hline & Availability of resources & \\
\hline & Loyalty & \\
\hline \multirow{3}{*}{$\begin{array}{l}\text { Behaviors that encourage } \\
\text { innovation }\end{array}$} & Mistake handling & \multirow{3}{*}{$\begin{array}{l}\text { (CORMICAN; O'SULLIVAN, 2004; GOMES; MACH- } \\
\text { ADO; ALEGRE, 2015; MARTINS; MARTINS; TER- } \\
\text { BLANCHE, 2004; MARTINS; TERBLANCHE, 2003; } \\
\text { MURAT AR; BAKI, 2011; NKOSI; ROODT, 2004) }\end{array}$} \\
\hline & Idea generation & \\
\hline & Risk-taking & \\
\hline \multirow{3}{*}{ Communication } & Communication between departments & \multirow{3}{*}{$\begin{array}{l}\text { (DOMBROWSKI et al., 2007; GOMES; MACHADO; } \\
\text { ALEGRE, 2015; MARTINS; MARTINS; TERBLANCHE, } \\
\text { 2004; MARTINS; TERBLANCHE, 2003; MURAT AR; } \\
\text { BAKI, 2011; NKOSI; ROODT, 2004) }\end{array}$} \\
\hline & Open communication & \\
\hline & Shared information & \\
\hline
\end{tabular}

Source: developed by the authors.

Regarding 'structure', the lowest mean was identified in the question of formality and standardization of processes, and the highest one pointed to the importance of encouraging teamwork. On the other hand, the 'support' category had a lower overall mean (4.47) and the highest standard deviations of the dataset, with the minimum mean related to the freedom to comment on the variety and type of training received.

In relation to the 'stimuli', the lowest mean (4.59) was observed in the score referred to question I 'All ideas are considered' and the highest mean (5.03), which relates to the encouragement that the employees receive to speak and learn from others. Finally, in the communication category, the lowest mean corresponded to question I related to good interde- partmental communication (4.49) and the highest (5.08) to 'Communication of decisions obeys the hierarchy in the company'.

\section{Correlation Analysis}

Pearson's correlation matrix indicated moderate and highly significant positive relationships in most of the variables and high coefficients (HAIR et al., 2009), as shown in Table 6. The strongest relationships (coefficient $>0.50)(C O H E N$, 1992) were seen in the factors (Table 6): vision and mission are future-oriented' and 'vision and mission are strongly market-oriented'; 'all the ideas are considered' and 'employees are encouraged to share and learn as a team'; 'there is a good communication between business units' and 'information is commonly shared among employees'. 
TABLE 5 - Descriptive Statistics

\begin{tabular}{l|l|l|l}
\hline Variables & Mean & Standard Deviation & N analysis \\
\hline strategy1 & 5.45 & 1.542 & 587 \\
\hline strategy2 & 5.36 & 1.488 & 587 \\
\hline strategy3 & 5.34 & 1.514 & 587 \\
\hline strategy4 & 4.66 & 1.561 & 587 \\
\hline strategy5 & 5.36 & 1.512 & 587 \\
\hline strategy6 & 5.24 & 1.433 & 587 \\
\hline strategy7 & 5.15 & 1.578 & 587 \\
\hline structure1 & 4.73 & 1.631 & 587 \\
\hline structure2 & 5.22 & 1.684 & 587 \\
\hline structure3 & 5.21 & 1.476 & 587 \\
\hline structure4 & 5.26 & 1.588 & 587 \\
\hline structure5 & 4.78 & 1.765 & 587 \\
\hline support1 & 4.99 & 1.708 & 587 \\
\hline support2 & 4.62 & 1.894 & 587 \\
\hline support3 & 4.83 & 1.713 & 587 \\
\hline support4 & 4.47 & 1.708 & 587 \\
\hline support5 & 4.62 & 1.805 & 587 \\
\hline stimulus1 & 4.59 & 1.693 & 587 \\
\hline stimulus2 & 5.03 & 1.692 & 587 \\
\hline stimulus3 & 4.79 & 1.674 & 587 \\
\hline stimulus4 & 4.66 & 1.770 & 587 \\
\hline commun1 & 4.49 & 1.788 & 587 \\
\hline comnun2 & 4.52 & 1.699 & 587 \\
\hline commun3 & 4.81 & 1.533 & 587 \\
\hline commun4 & 5.08 & 1.566 & 587 \\
\hline Soure: & & \\
\hline
\end{tabular}

Source: developed by the authors.

These results show that the more employees are encouraged to speak and learn from each other, the more motivated they will be to keep their knowledge and skills updated. Furthermore, favorable interdepartmental communication allows information to be shared clearly among workers granting greater union in work teams, a fact that benefits vertical relations of the employees with their respective heads.

\section{Exploratory Factor Analysis}

Next, an exploratory factor analysis was carried out on the 25 variables of the instrument with orthogonal Varimax rotation in the sample of 587 participants. The Kai-
ser-Meyer-Olkin (KMO) measure showed very good sample adequacy for the analysis $(K M O=0.957)($ MARÔCO, 20II). The Bartlett sphericity test [Chi-square (300) $=7806.35 \mathrm{I}, \mathrm{P}<0.000]$ indicated that correlations between items are sufficient for performing the analysis. Also, since all the measures were collected simultaneously at the same time, at this stage we run the Harman single-factor test, which yielded $40.67 \%$ variance for the first factor, suggesting that common method variance does not have an effect on our results (MACKENZIE; PODSAKOFF, 2012; PODSAKOFF et al., 2003).

The initial analysis showed that three components followed the Kaiser criterion of greater than I, which explained $55.62 \%$ 


\begin{tabular}{|c|c|c|c|c|c|c|c|c|c|c|c|c|c|c|c|c|c|c|c|c|c|c|c|c|c|c|}
\hline$\stackrel{2}{N}$ & & & & & & & & & & & & & & & & & & & & & & & & & - & \\
\hline$\stackrel{d}{\sim}$ & & & & & & & & & & & & & & & & & & & & & & & & - & $\begin{array}{l}8 \\
0\end{array}$ & \\
\hline N & & & & & & & & & & & & & & & & & & & & & & & - & $\begin{array}{l}0 \\
0 \\
0\end{array}$ & 苜 & \\
\hline $\mathbb{N}$ & & & & & & & & & & & & & & & & & & & & & & - & $\begin{array}{l}0 \\
0 \\
0\end{array}$ & 告 & $\stackrel{*}{*}$ & \\
\hline $\bar{N}$ & & & & & & & & & & & & & & & & & & & & & - & $*$ & $*$ & $*$ & ${ }_{*}^{*}$ & \\
\hline ฉ & & & & & & & & & & & & & & & & & & & & - & 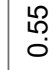 & $\stackrel{*}{*}$ & $\stackrel{*}{*}$ & $\underset{*}{*}$ & $\stackrel{*}{*}$ & \\
\hline$\stackrel{\circ}{\longrightarrow}$ & & & & & & & & & & & & & & & & & & & - & ़ְ & 望 & $*$ & $*$ & $\begin{array}{l}5 \\
50 \\
0\end{array}$ & $*$ & \\
\hline$\stackrel{\infty}{-}$ & & & & & & & & & & & & & & & & & & $r$ & ర్ & 占 & N & $\begin{array}{l}\tilde{N} \\
0 \\
0 \\
0\end{array}$ & $\stackrel{*}{*}$ & ${ }_{*}^{*}$ & $\stackrel{*}{*}$ & \\
\hline 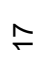 & & & & & & & & & & & & & & & & & $r$ & : & $\underset{*}{*}$ & مُ & $*$ & $\stackrel{*}{*}$ & ${ }_{*}^{*}$ & $\underset{*}{*}$ & * & \\
\hline$\stackrel{\varphi}{\circ}$ & & & & & & & & & & & & & & & & $r$ & مُ & م్ & $*$ & $\stackrel{*}{*}$ & $\stackrel{*}{*}$ & $\stackrel{*}{*}$ & $\stackrel{*}{*}$ & $\underset{*}{*}$ & $\stackrel{*}{*}$ & \\
\hline$\stackrel{2}{\leftarrow}$ & & & & & & & & & & & & & & & $r$ & 掼 & 占 & مُ & مै & 足 & مُ & 足 & $\stackrel{*}{*}$ & $\stackrel{*}{*}$ & $\underset{*}{*}$ & \\
\hline$\underset{\square}{ }$ & & & & & & & & & & & & & & $r$ & $\begin{array}{l}0 \\
\stackrel{0}{0} \\
0\end{array}$ & * & 足 & : & $*$ & $*$ & $\stackrel{*}{*}$ & $\stackrel{*}{*}$ & $*$ & 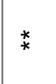 & $\stackrel{*}{*}$ & \\
\hline$\stackrel{m}{-}$ & & & & & & & & & & & & & - & $\begin{array}{l}8 \\
0\end{array}$ & $*$ & $\stackrel{*}{*}$ & זْ & $*$ & กิ & 苞 & * & $*$ & * & $*$ & $*$ & \\
\hline$\stackrel{\simeq}{\simeq}$ & & & & & & & & & & & & - & * & $\underset{*}{*}$ & * & $\stackrel{*}{*}$ & $\stackrel{*}{*}$ & * & $\underset{*}{*}$ & $\stackrel{*}{*}$ & * & * & $*$ & $*$ & $\stackrel{*}{*}$ & \\
\hline$F$ & & & & & & & & & & & - & స్ & * & * & * & $\stackrel{*}{*}$ & * & $*$ & 芯 & ז. & $*$ & * & $*$ & ${ }_{*}^{*}$ & * & P \\
\hline 우 & & & & & & & & & & - & סु & $\stackrel{*}{*}$ & $\underset{*}{*}$ & $\stackrel{*}{*}$ & $\stackrel{*}{*}$ & $\stackrel{*}{*}$ & $\stackrel{*}{*}$ & 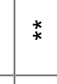 & $\stackrel{*}{*}$ & $\stackrel{*}{*}$ & $\stackrel{*}{*}$ & $\stackrel{*}{*}$ & $\stackrel{*}{*}$ & $\stackrel{*}{*}$ & * & \\
\hline$\sigma$ & & & & & & & & & - & $\underset{*}{*}$ & $\stackrel{*}{*}$ & $\stackrel{*}{*}$ & $\stackrel{*}{*}$ & * & $\stackrel{*}{*}$ & $\stackrel{*}{*}$ & $\stackrel{*}{*}$ & $\stackrel{*}{*}$ & $\stackrel{*}{*}$ & $\stackrel{*}{*}$ & 类 & $\stackrel{*}{*}$ & $\stackrel{*}{*}$ & $\stackrel{*}{*}$ & $\stackrel{*}{*}$ & \\
\hline$\infty$ & & & & & & & & $r$ & * & 类 & * & $\underset{*}{*}$ & * & 贲 & * & $*$ & * & * & * & $*$ & * & $\stackrel{*}{*}$ & * & 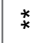 & 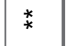 & \\
\hline 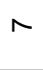 & & & & & & & $r$ & 跑 & $*$ & $\underset{*}{*}$ & $\stackrel{*}{*}$ & $\underset{*}{*}$ & $\stackrel{*}{*}$ & * & $\underset{*}{*}$ & $\underset{*}{*}$ & $\stackrel{*}{*}$ & * & $*$ & $\stackrel{*}{*}$ & $\stackrel{*}{*}$ & $\stackrel{*}{*}$ & $*$ & $\underset{*}{*}$ & $\stackrel{*}{*}$ & \\
\hline 0 & & & & & & $r$ & $\begin{array}{l}\text { 芯 } \\
0\end{array}$ & $\stackrel{*}{*}$ & * & $\stackrel{*}{*}$ & $\underset{*}{*}$ & $\underset{*}{*}$ & $*$ & $\stackrel{*}{*}$ & $*$ & $\stackrel{*}{*}$ & $\stackrel{*}{*}$ & $*$ & $*$ & $*$ & $\stackrel{*}{*}$ & $\stackrel{*}{*}$ & $*$ & $* *$ & $*$ & \\
\hline ما & & & & & $r$ & $\stackrel{8}{\circ}$ & $\stackrel{*}{*}$ & $\stackrel{*}{*}$ & $\stackrel{*}{*}$ & $*$ & $\stackrel{*}{*}$ & $\underset{*}{*}$ & $\stackrel{*}{*}$ & $\stackrel{*}{*}$ & $\underset{*}{*}$ & * & $\stackrel{*}{*}$ & $\stackrel{*}{*}$ & $\stackrel{*}{*}$ & $\stackrel{*}{*}$ & $\stackrel{*}{*}$ & $\stackrel{*}{*}$ & $\stackrel{*}{*}$ & $\underset{*}{*}$ & $\underset{*}{*}$ & \\
\hline$\nabla$ & & & & - & $*$ & $\underset{*}{*}$ & $\stackrel{*}{*}$ & $\stackrel{*}{*}$ & * & $\stackrel{*}{*}$ & $\stackrel{*}{*}$ & $\stackrel{*}{*}$ & $*$ & * & * & $\stackrel{*}{*}$ & $\stackrel{*}{*}$ & $\stackrel{*}{*}$ & $\stackrel{*}{*}$ & $\stackrel{*}{*}$ & * & $\stackrel{*}{*}$ & $\stackrel{*}{*}$ & $\stackrel{*}{*}$ & $\stackrel{*}{*}$ & \\
\hline$m$ & & & - & * & $*$ & $\underset{*}{*}$ & in & $\stackrel{*}{*}$ & $\stackrel{*}{*}$ & $\stackrel{*}{*}$ & $\stackrel{*}{*}$ & $\underset{*}{*}$ & $\stackrel{*}{*}$ & $\stackrel{*}{*}$ & $\underset{*}{*}$ & * & $\stackrel{*}{*}$ & $\stackrel{*}{*}$ & $*$ & $\stackrel{*}{*}$ & $\stackrel{*}{*}$ & $\stackrel{*}{*}$ & $*$ & $\stackrel{*}{*}$ & * & \\
\hline$N$ & & - & $\stackrel{*}{*}$ & $\stackrel{*}{*}$ & $*$ & $\stackrel{*}{*}$ & * & $\stackrel{*}{*}$ & $\stackrel{*}{*}$ & $\stackrel{*}{*}$ & $\stackrel{*}{*}$ & $\stackrel{*}{*}$ & $\stackrel{*}{*}$ & $\stackrel{*}{*}$ & $\stackrel{*}{*}$ & $\stackrel{*}{*}$ & $\stackrel{*}{*}$ & $\stackrel{*}{*}$ & $\stackrel{*}{*}$ & $\stackrel{*}{*}$ & $\stackrel{*}{*}$ & ${ }^{*}$ & * & * & $\stackrel{*}{*}$ & \\
\hline$r$ & - & $\begin{array}{l}\infty \\
0 \\
0\end{array}$ & $\stackrel{*}{*}$ & $\stackrel{*}{*}$ & $\stackrel{*}{*}$ & $\underset{*}{*}$ & $\stackrel{*}{*}$ & $\stackrel{*}{*}$ & $\underset{*}{*}$ & $\underset{*}{*}$ & $\underset{*}{*}$ & $\underset{*}{*}$ & $\underset{*}{*}$ & $\stackrel{*}{*}$ & $\underset{*}{*}$ & * & $\stackrel{*}{*}$ & $\stackrel{*}{*}$ & $\stackrel{*}{*}$ & $\stackrel{*}{*}$ & $\stackrel{*}{*}$ & $\underset{*}{*}$ & $\stackrel{*}{*}$ & $\underset{*}{*}$ & $\stackrel{*}{*}$ & \\
\hline $\begin{array}{l}\frac{\infty}{0} \\
\frac{0}{0} \\
\frac{0}{\pi} \\
\frac{\pi}{5}\end{array}$ & 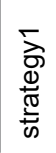 & 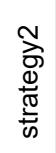 & 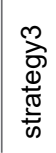 & 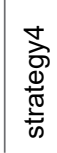 & 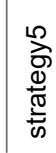 & $\begin{array}{l}0 \\
\text { बे. } \\
\frac{\Phi}{\pi} \\
\frac{\pi}{\omega}\end{array}$ & 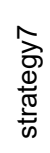 & 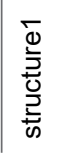 & 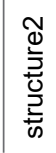 & 总 & 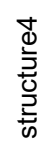 & 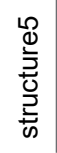 & $\begin{array}{l}\bar{E} \\
\overline{0} \\
\frac{0}{3} \\
\omega\end{array}$ & 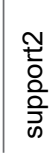 & 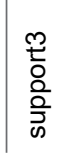 & 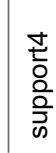 & 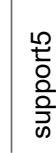 & $\begin{array}{l}\overline{\frac{c}{D}} \\
\overline{\bar{z}} \\
\overline{\bar{c}}\end{array}$ & 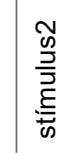 & 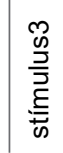 & 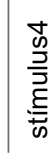 & 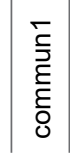 & 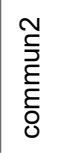 & 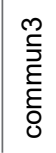 & 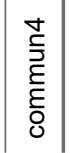 & 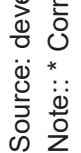 \\
\hline
\end{tabular}


of the variance. The scree plot showed that the three components are positioned prior to inflection. Considering the sample size and the convergence between the scree plot and the Kaiser criterion, this was the number of components maintained in the final analysis. The rotated eigenvalues for the three components were $5.137,4.950$ and 3.817 respectively, according to Table 7. It should be noted that the Varimax rotation optimizes the factorial structure and the relative importance of the remaining factors is equalized.

Table 8 shows the component matrix rotated by the Varimax method, the factors, and their communalities. Corrar et al.

TABLE 7 - Total variance explained

\begin{tabular}{|c|c|c|c|c|c|c|c|c|c|}
\hline \multirow{2}{*}{ 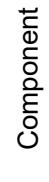 } & \multirow[b]{2}{*}{ Total } & \multirow[b]{2}{*}{$\begin{array}{c}\% \text { of } \\
\text { variance }\end{array}$} & \multirow[b]{2}{*}{ cumulative \% } & \multicolumn{3}{|c|}{ Extraction Sums of Squared Loadings } & \multicolumn{3}{|c|}{ Rotation Sums of Squared Loadings } \\
\hline & & & & Total & $\begin{array}{c}\% \text { of } \\
\text { variance }\end{array}$ & $\begin{array}{c}\text { cumulative } \\
\%\end{array}$ & Total & $\begin{array}{c}\% \text { of } \\
\text { variance }\end{array}$ & $\begin{array}{c}\text { cumulative } \\
\%\end{array}$ \\
\hline 1 & 11.128 & 44.514 & 44.514 & 11.128 & 44.514 & 44.514 & 5.137 & 20.549 & 20.549 \\
\hline 2 & 1.623 & 6.493 & 51.006 & 1.623 & 6.493 & 51.006 & 4.950 & 19.801 & 40.349 \\
\hline 3 & 1.152 & 4.609 & 55.615 & 1.152 & 4.609 & 55.615 & 3.817 & 15.266 & 55.615 \\
\hline 4 & .903 & 3.612 & 59.227 & & & & & & \\
\hline 5 & .855 & 3.418 & 62.645 & & & & & & \\
\hline$\ldots$ & $\ldots$ & $\ldots$ & $\ldots$ & & & & & & \\
\hline 25 & .248 & .990 & 100.000 & & & & & & \\
\hline
\end{tabular}

Source: developed by the authors. Note: Extraction Method: Principal Component Analysis.

TABLE 8 - Rotated Component Matrix and Communalities

\begin{tabular}{l|c|c|c|c|c}
\hline \multirow{2}{*}{ Variables } & \multicolumn{2}{|c|}{ Component } & \multicolumn{2}{c}{ Commonalities } \\
\cline { 2 - 6 } & 1 & 2 & & Initial & Extraction \\
\hline strategy1 & 0.769 & & & 1 & 0.638 \\
\hline strategy2 & 0.739 & & & 1 & 0.587 \\
\hline strategy6 & 0.628 & & & 1 & 0.577 \\
\hline strategy7 & 0.578 & & & 1 & 0.558 \\
\hline support5 & & 0.633 & & 1 & 0.632 \\
\hline support3 & & 0.692 & & 1 & 0.611 \\
\hline support2 & & 0.712 & & 1 & 0.605 \\
\hline stimulus1 & & 0.604 & & 1 & 0.602 \\
\hline stimulus3 & & 0.583 & & 1 & 0.591 \\
\hline stimulus2 & & 0.732 & & 1 & 0.579 \\
\hline support1 & & 0.676 & & 1 & 0.576 \\
\hline support4 & & 0.543 & & 1 & 0.547 \\
\hline stimulus4 & & & 0.721 & 1 & 0.518 \\
\hline commun3 & & & 0.744 & 1 & 0.697 \\
\hline commun2 & & 0.750 & 1 & 0.693 \\
\hline commun1 & & & 0.701 & 1 & 0.657 \\
\hline commun4 & & & & & 0.597 \\
\hline Source: & & & & & \\
\hline
\end{tabular}

Source: developed by the authors.

Note: Extraction Method: Principal Component Analysis. Rotation Method: Varimax with Kaiser Normalization. Rotation converged in 6 iterations. 
(2007) suggest that values above 0.50 can be considered acceptable; therefore, variables with coefficients lower than this value were removed from the groupings.

Then, Cronbach's alpha was checked for variables corresponding to each factor. This method uses a scale of 0 to I, with values from 0.60 to 0.70 considered the lower limit of acceptability. In the case of this study, $\alpha$ for factor I was 0.805 ; $\alpha$ of factor 2 was 0.905 and $\alpha$ of factor 3 was 0.847 , thus all of them presented a moderate to high reliability (MARÔCO, 20II). In figure I, the proposed model, with the variables and dimensions regrouped.

The results show that the model of a culture that can promote and encourage creativity and innovation can be explained by three elements or determinants: strategy, innovation stimulus, and communication.

Strategy, composed by Strategy I (vision and mission focused on the future), Strategy2 (market-oriented vision and mission), Strategy6 (goals oriented towards effectiveness), Strategy 7 (alignment of the aims of the goals at all levels), in this order of importance (see table 8), which presented high and positive loadings.

The strategic orientation towards innovation has been getting more attention in academic literature in recent years, and there is evidence of its positive effects on firm performance (FAHIM; ROHAIZAT, 2017; SANZ-VALLE et al., 20I I). The strategy determinant is linked to the organization's guidelines for achieving goals and objectives, and the formal and standardized long-term planning process used to define and achieve personal and organizational goals. According to Martins and Terblanche (2003), the inclusion of innovation goals to the strategy of the organization is the first step to prove the organization's commitment to innovation. Integrating innovation into mission and vision or into the belief system is essential to establish a clear direction for the company that is willing to be innovative.

Values and norms that stimulate innovation are manifested in the goals that guide

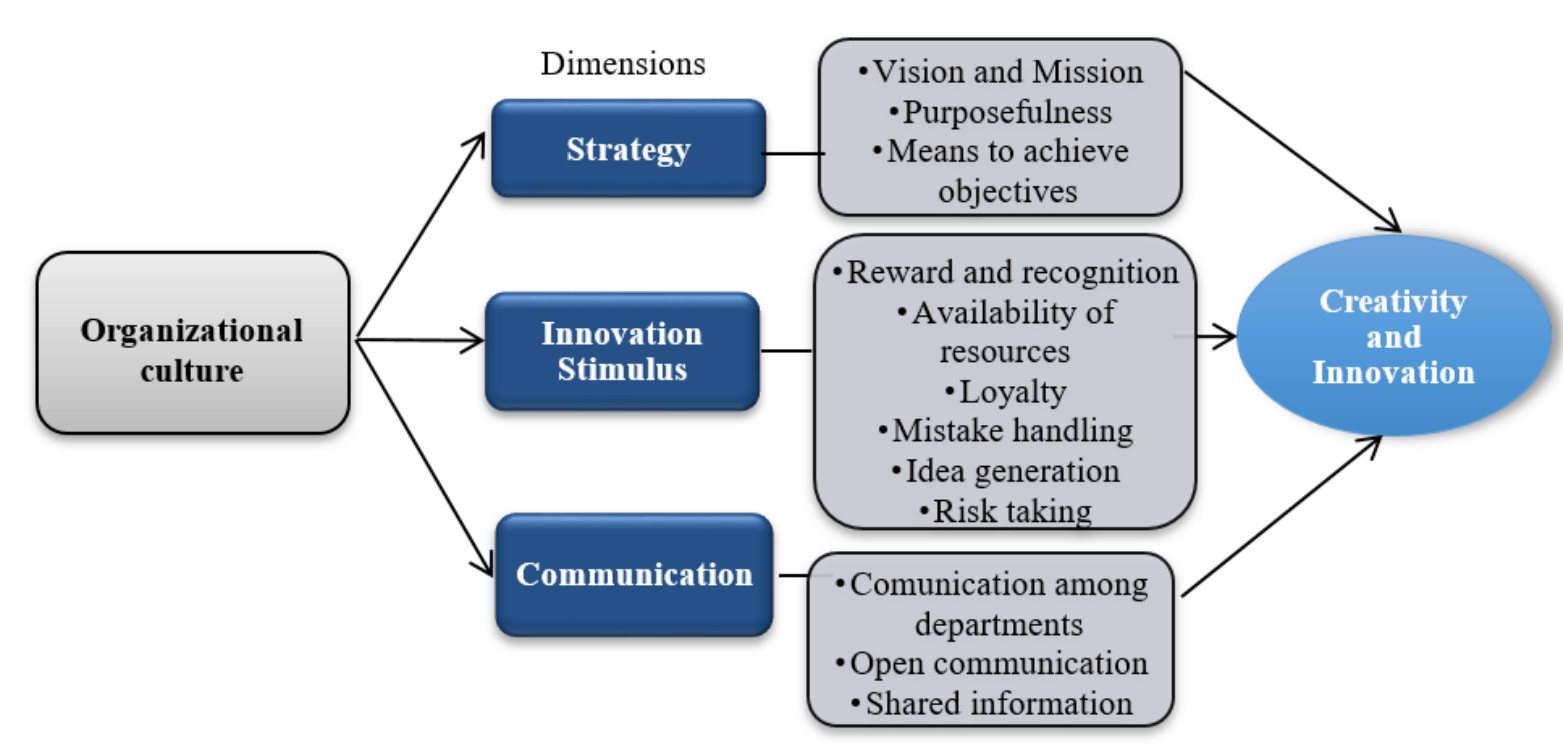

FIGURE 1 - Dimensions of organizational culture that encourage creativity and Innovation

Source: developed by the authors. 
the actions of the organization and are aimed to integrate the organization internally and to the external environment. According to Arad et al. (1997), organizational goals represent the priorities and values of the organization and, as a consequence, can promote or hinder innovation.

Organizations that have a clear vision of the future are the most inclined to make innovation happen. An innovation strategy generates the development and implementation of new products and services (MARTINS; MARTINS, 2002). Mission and vision statements unify dissimilar groups to focus on the common goal of the organization (DOMBROWSKI et al., 2007).

In the Stimulus to innovation determinant, the following variables were grouped: Support5 (rewards in recognition to creativity and innovation), Support3 (general access to information), Support2 (financial and non-financial rewards for efficiency), Stimulus I (consideration of all ideas), Stimulus3 (constant update of knowledge and activities), Stimulus2 (encouragement to talk and learn in team), Support I (rewards as a tool for motivation), Support4 (training feedback) and Stimulus 4 (constructive conflict resolution) that presented high and positive loadings, being classified as a characteristic aspect of participative working environments, of flexible and open organizations, that promote a culture of innovation based on trust among people involved (CORNEJO; MUÑOZ, 20l0).

According to Martins and Terblanche (2003) the rewards and recognition, as well as the availability of resources, such as time, information technology, training, and creative people, are mechanisms that support creativity and innovation.

Amabile et al. (1996) consider intrin- sic motivation as the form of motivation most associated with creativity. When the intrinsic motivation is high, the members of the organization get involved and can seek more information about the activity, breaking with the usual styles of idea generation (AMABILE et al., 2004). Cultures focused on innovation privilege the process of continuous learning and encourage its employees to develop new ideas, without the concern of harming them by eventual failures, favoring creativity and innovation (MARTINS; TERBLANCHE, 2003). Previous studies show that employees' innovative behaviors are stimulated by innovative cultures (MARTINS; TERBLANCHE, 2003; NARANJO-VALENCIA; JIMENEZJIMENEZ; SANZ-VALLE, 20 I7).

The third determinant, Communication encompassed all variables related to communication: Communication 3 (union and open communication in work teams), Communication 2 (clear sharing of information among workers), Communication I (fluid interdepartmental communication) and Communication 4 (communication of hierarchical decisions). These variables also presented high and positive loadings.

Work teams and internal communication are also related to the culture and performance of innovation. There is empirical evidence that shows that the generation of creative ideas is strongly related to open communication environments (NARANJO-VALENCIA; JIMENEZ-JIMENEZ; SANZ-VALLE, 2017).

It is beneficial for firms to nurture an innovative organizational culture by instituting mechanisms and structures which foster new ideas and ways of thinking and operating as this is likely to improve firm performance. The introduction, adoption, 
and diffusion of innovations can be facilitated in the organizations with mechanisms to encourage and foster an innovative culture (UZKURT et al., 20I3).

Through open communication, it is possible to share values and exchange information and experiences with the participation of all organizational levels. The more information the employees have, the more involved they will be with the firm's vision and mission, and therefore with the goals and objectives of the organization. Schein $(2017,1993)$ emphasizes that the establishment of communication practices between groups or different hierarchical levels eliminates bureaucratic processes, providing a higher degree of consistency and creativity since individuals share a common thought process and become familiar with the problems and goals of the organization.

\section{FINAL REMARKS}

The objective of this paper was to analyze the elements of the organizational culture that foster innovation development in organizations of the textile industry of the States of Santa Catarina and Parana, Southern Brazil. To that end, quantitative and exploratory research was developed through multivariate data treatment using exploratory factor analysis, with primary data extracted of a survey applied in 587 respondents, employees of all organizational levels of 64 small, medium and large textile companies.

The literature that deals with the relationship between organizational culture and innovation points out that the elements of culture, such as shared values, beliefs and behaviors, influence the development of innovation in two ways: on the one hand, through the process of socializa- tion in which individuals learn acceptable behaviors and activities; and on the other hand, when values, assumptions, and beliefs influence management structure, policies, and management practices.

In the organizational culture and innovation literature review, it was observed little consensus, on which determinants influence organizational culture to foster innovation. Martins and Martins (2002) proposed a model of analysis based on seven dimensions of culture: strategic vision and mission, customer focus (external environment), means to reach objectives, management processes, team needs and objectives, interpersonal relationships and leadership and five determinants of innovation: strategy, structure, support mechanisms, behaviours that stimulate innovation and communication, which served as the starting point for the elaboration of this study.

The results of the exploratory factor analysis performed in this research pointed to three cultural factors, as determinants of innovation: Strategy, Stimulus to Innovation and Communication. The strategy (vision and mission, determination and means to accomplish objectives) is linked to the organization's guidelines for achieving goals and objectives, being a long-term formalized and standardized planning process used to plan and achieve personal and organizational goals. Organizational goals represent the priorities and values of the firm and, as a consequence, can promote or hinder innovation.

The Innovation Stimulus dimension (rewards and recognition, resource availability, loyalty, mistake handling, ideas generation, and risk-taking), as well as the availability of resources (such as time, information technology, training, and creative people), are mechanisms which support innovation. 
Communication (communication among departments, open communication, and shared information) is related to the establishment of best communication practices between groups or different hierarchical levels, eliminating processes considered as bureaucratic, providing a higher degree of consistency and creativity.

The contribution of this study resulted in a model of analysis of the relationship between organizational culture and innovation, which regroups and simplifies in three dimensions and 17 variables the determinants of the promotion of creativity and innovation, avoiding the overlapping of some items of analysis, aspect criticized by several authors, having been validated em- pirically in the textile sector. This may allow organizations to determine the degree to which organizational culture supports innovation, which is essential in environments of constant change.

As a limitation of the study, it is possible to point out at the approach of complex and controversial concepts such as culture and innovation that can be reflected in the operationalization of constructs and variables, besides the properly quantitative-statistics issues, such as population definition, sample, and industry. Future research may follow this work by considering a confirmatory factor analysis with the identification of other explanatory variables or applying the proposed model in other industries. 


\section{REFERÊNCIAS}

ABIT. Brazilian Têxtile Manufacturing Association. Associação Brasileira da Indústria Têxtil e de Confecção. Disponível em: <http://www.abit.org. br/>.Acesso em: I jan. 2017.

ABIT. Associação Brasileira da Indústria Têxtil e de Confecção. Perfil do Setor. 2017. Disponível em: <http://www.abit.org. br/cont/perfil-do-setor>. Acesso em: 9 abr. 2018.

AHMED, A.; OTHMAN, I. B. L. Relationship between Organizational Resources and Organizational Performance: A Conceptualize Mediation Study. European Online Journal of Natural and Social Sciences, v. 6, n. I, p. 10, 2017.

AHMED, P. Culture and climate for innovation. European journal of innovation management, v. I, n. I, p. 30-43, 1998.

AMABILE, T. M. et al. Assessing the work environment for creativity. Academy of management journal, v. 39, n. 5, p. I I54- I I84, 1996.

AMABILE, T. M. et al. Leader behaviors and the work environment for creativity: Perceived leader support. The Leadership Quarterly, v. I5, n. I, p. 5-32, 2004.

ANDERSON, S. Enterprise Architecture for Innovation Realization and Sustainability. In: Leadership, Innovation and Entrepreneurship as Driving Forces of the Global Economy. New York: Springer, 20 I7. p. 69-76.

ANDRIOPOULOS, C.; LEWIS, M.W. Managing innovation paradoxes: Ambidexterity lessons from leading product design companies. Long range planning, v. 43, n. I, p. 104-122, 2010.

ARAD, S.; HANSON, M. A.; SCHNEIDER, R. J. A framework for the study of relationships between organizational characteristics and organizational innovation. The Journal of Creative Behavior, v. 3 I, n. I, p. 42-58, 1997.

BARNEY, J. B. Organizational Culture : Can It Be a Source of Sustained Competitive Advantage? The Academy of Management Review, v. I I, n. 3, p. 656665, 1986.

COHEN, J. Statistical power analysis. Current directions in psychological science, v. I, n. 3, p. 98I0I, 1992.

CORMICAN, K.; O'SULLIVAN, D. Auditing best practice for effective product innovation management. Technovation, v. 24, n. 10 , p. 819-829, 2004.

CORNEJO, M.; MUÑOZ, E. Percepción de la innovación: cultura de la innovación y capacidad innovadora. In: Pensamiento Iberoamericano. n. 5, v. 2 ed. p. |21-139.

CORRAR, L. J.; PAULO, E.; DIAS FILHO, J.M.Análise multivariada: para os cursos de administração, ciências contábeis e economia. São Paulo: Atlas, p. 280-323, 2007.

DAMANPOUR, F. Organizational innovation: A meta-analysis of effects of determinants and moderators. Academy of management journal, v. 34, n. 3, p. 555-590, 1991.

DAMANPOUR, F.; SZABAT, K. A.; EVAN, W. M. The relationship between types of innovation and organizational performance. Journal of Management Studies, v. 26, n. 6, p. 587-602, 1989.

DANDRIDGE, T. C. et al. Symbolism : A Topic Organizational To Analysis Expand Organizational University of Pittsburgh. v. 5, n. I, p. 77-82, 2008.

DANDRIDGE, T. C.; MITROFF, I.; JOYCE, W. F. Organizational symbolism: A topic to expand orga- nizational analysis. Academy of Management Review, v. 5, n. I, p. 77-82, 1980.

DOBNI, C. B. Measuring innovation culture in organizations: The development of a generalized innovation culture construct using exploratory factor analysis. European Journal of Innovation Management, v. II, n. 4, p. 539559, 2008.

DOMBROWSKI, C. et al. Elements of innovative cultures. Knowledge and Process Management, v. I4, n. 3, p. 190-202, 2007.

FAHIM, N.; ROHAIZAT, B. Analyzing the Mediating Effect of Innovation Capability on Strategic Orientations in Agricultural Malaysia. WSEAS Transactions on Business and Economics, v. 14, n. I, p. 253-262, 2017.

FARIA, M.; FONSECA, M. V. Cultura de Inovação: Conceitos e Modelos Teóricos/Culture of Innovation: Concepts and Theoretical Models. Revista de Administração Contemporânea, v. 18, n. 4, p. 372, 2014.

FIESC. Federação das Indústrias do Estado de Santa Catarina - Santa Catarina em dados 20 I 7. Florianópolis: FIESC, 2017. GOMES, G.; DEL PRÁ NETTO MACHADO, D.; ALEGRE, J. Determinants of innovation culture: A study of textile industry in Santa Catarina. BBR-Brazilian Business Review, v. 12, n. 4, 2015.

GOMES, G.; MACHADO, D. D. P. N.; ALEGRE, J. Determinantes da Cultura de Inovação: Estudo na Indústria Têxtil de Santa Catarina. Brazilian Business Review, v. I2, n. 4, p. 105, 2015.

HAIR, J. F. et al. Análise multivariada de dados. Porto Alegre: Bookman Editora, 2009. 
HU, M.-C. Technological innovation capabilities in the thin film transistor-liquid crystal display industries of Japan, Korea, and Taiwan. Research Policy, v. 4I, n. 3, p. 54I-555, 2012.

HURLEY, R. F.; HULT, G. T. M.; KNIGHT, G.A. Innovativeness and capacity to innovate in a complexity of firm-level relationships: A response to Woodside (2004). Industrial Marketing Management, v. 34, n. 3, p. 28I-283, 2005.

JASKYTE, K.; KISIELIENE, A. Organizational innovation: A comparison of nonprofit human-service organizations in Lithuania and the United States. International Social Work, v. 49, n. 2, p. I65176, 2006.

LEMON, M.; SAHOTA, P. S. Organizational culture as a knowledge repository for increased innovative capacity. Technovation, v. 24, n. 6, p. 483-498, 2004.

LOUIS, M. R.A cultural perspective on organizations: The need for and consequences of viewing organizations as culture-bearing milieux. Human Systems Management, v. 2, n. 4, p. 246-258, I98I.

MACKENZIE, S. B.; PODSAKOFF, P. M. Common method bias in marketing: causes, mechanisms, and procedural remedies. Journal of retailing, v. 88, n. 4, p. 542-555, 2012.

MARÔCO, J. Análise estatística com o SPSS Statistics. 5 ed. ed. Pero Pinheiro: ReportNumber, Lda, 20I I.

MARTINS, E.; MARTINS, N. An organisational culture model to promote creativity and innovation. SA Journal of Industrial Psychology, v. 28, n. 4, p. 58-65, 2002.

MARTINS, E.; MARTINS, N.; TERBLANCHE, F. An organizational culture model to stimulate creativity and innovation in a university library. In: Advances in Library
Administration and Organization. Emerald Group Publishing Limited, 2004. p. 83-I 30.

MARTINS, E.;TERBLANCHE, F. Building organisational culture that stimulates creativity and innovation. European Journal of Innovation Management, v. 6, n. I, p. 64-74, 2003.

MURAT AR, I.; BAKI, B. Antecedents and performance impacts of product versus process innovation: Empirical evidence from SMEs located in Turkish science and technology parks. European Journal of Innovation Management, v. I4, n. 2, p. I72-206, 20 I I.

NARANJO-VALENCIA,J.C.;JIMÉNEZJIMÉNEZ, D.;SANZ-VALLE, R. Innovation or imitation? The role of organizational culture. Management Decision, v. 49, n. I, p. 55-72, 20 I I. NARANJO-VALENCIA, J. C.; JIMENEZ-JIMENEZ, D.; SANZVALLE, R. Impact of Organisational Culture on New Product Success:an Empirical Study of Spanish Firms. European Management Review, 2017.

NDUBISI, N.; AGARWAL, J. Quality performance of SMEs in a developing economy: direct and indirect effects of service innovation and entrepreneurial orientation. Journal of Business \& Industrial Marketing, v. 29, n. 6, p. 454-468, 2014.

NKOSI, T. J.; ROODT, G. An assessment of bias and fairness of the culture assessment instrument. SA Journal of Human Resource Management, v. 2, n. 2, p. 24-36, 2004.

OECD. Oslo Manual. Guidelines for Collecting and Interpreting Innovation Data, 2005.

OECD. Innovation Strategy 2015 : An agenda for policy action. Meeting of the OECD Council at Ministerial Level. Anais...Paris:
Meeting of the OECD Council at Ministerial Level, 2015

OUCHI,W.Theory Z: How American business can meet the Japanese challenge. Business Horizons, v. 24, n. 6, p. 82-83, 198I.

PADILHA, C. K.; GOMES, G. Innovation culture and performance in innovation of products and processes: a study in companies of textile industry. RAI Revista de Administração e Inovação, v. I3, n. 4, p. 285-294, 20 I6.

PETRAKIS, P. E.; KOSTIS, P. C.; VALSAMIS, D. G. Innovation and competitiveness: Culture as a longterm strategic instrument during the European Great Recession. Journal of Business Research, v. 68, n. 7, p. |436-|438, 2015.

PODSAKOFF, P. M. et al. Common method biases in behavioral research: A critical review of the literature and recommended remedies. Journal of applied psychology, v. 88, n. 5, p. 879, 2003.

RICHARDSON, R. J. Pesquisa social: métodos e técnicas. São Paulo:Atlas, 2007.

SANZ-VALLE, R. et al. Linking organizational learning with technical innovation and organizational culture. Journal of Knowledge Management, v. I5, n. 6, p. 997 $1015,2011$.

SCHEIN, E. H. Culture as an environmental context for careers. Journal of Organizational Behavior, v. 5, n. I, p. 7I-8I, 1984.

SCHEIN, E. H. On dialogue, culture, and organizational learning. Organizational dynamics, v. 22, n. 2, p. 40-5I, 1993.

SCHEIN, E. H. Organizational Culture and Leadership. 5. ed. Hoboken:Wiley, 2017.

SCHUMPETER, J. A. The theory of economic development. Cambridge, Mass.: Harvard University Press, 1997. 
SMIRCICH, L. Concepts of Culture TUSHMAN, M. L. Winning through and Organizational Analysis. Administrative Science Quarterly, v. 28, n. 3, p. 339-358, 1983.

TEDDLIE, C.; YU, F. Mixed methods sampling: A typology with examples. Journal of mixed methods research, v. I, n. I, p. 77-I00, 2007.

TIAN, M. et al. How does culture influence innovation? A systematic literature review. Management Decision, v. 56, n. 5, p. 1088-II07, 2018. innovation. Strategy \& Leadership, v. 25 , n. 4, p. 14-19, I abr. 1997.

UZKURT, C. et al. Role of innovation in the relationship between organizational culture and firm performance:A study of the banking sector in Turkey. European Journal of innovation management, $v$. 16, n. I, p. 92-II7, 2013.

ZDUNCZYK, K.; BLENKINSOPP, J.
Do organisational factors support creativity and innovation in Polish firms? European Journal of Innovation Management, v. 10, n. I, p. 25-40, 2007.

ZHENG, W.; YANG, B.; MCLEAN, G. Linking organizational culture, structure, strategy, and organizational effectiveness: Mediating role of knowledge management. J. of Business research, v. 63, n. 7, p. 763-77I, 2010. 